\title{
PALEOPALYNOLOGICAL DATA ABOUT LABIATAE AND RANUNCULACEAE FAMILIES IN ELBASAN REGION
}

DOI: http://dx.doi.org/10.18509/GBP.2015.09

UDC: 561.9(496.5)

\author{
Admir Jançe \\ "Aleksander Xhuvani” Elbasan University, Elbasan, Albania.
}

\begin{abstract}
Elbasan city is one of the biggest cities of Albania which is situated in the middle of Albania state. Many different biological studies have been realized in Elbasan area these two last decades.

This study provides some paleopalynological data about the dispersion of Labiatae and Ranunculaceae families during Holocene period in the area where is situated Elbasan city. The goal of this paper is to present the correlation between the depth and dispersion of Labiatae and Ranunculaceae families on different periods of time. For this purpose we took some samples from various layers of soil, starting from the surface to four meters depth.

A pollen sample is obtained by acetolysis, which entails heating the soil sample with a mixture of one part concentrated sulphuric acid and nine parts acetic anhydride. Palynological data for these two families will presented for the first time in this scientific international activity.

According to the analyses of these samples we found out several interesting data that showed clearly the correlation between the depth and number of spores for these two families.

Comparing these data we found out that, the dispersion level of Labiatae family is higher than the dispersion level of Ranunculaceae family.
\end{abstract}

Keywords: Paleopalynological, Holocene period, pollen, Labiatae, Ranunculaceae.

\section{INTRODUCTION}

The given material presents paleopalynological data of Holocene deposits in Elbasan district. Pollen and spores can undoubtedly be preserved because the outer wall of the grains is extraordinarily resistant $(5,8)$. Plant microfossils of these two families have not been studied previously from any of the localities in Elbasan and there aren't any studies by neither native or foreign authors for spore and pollen content data about these plants in Holocene deposits in our country $(9,10)$. Information on the method of collection, preservation and laboratory processing of the pollen grains of these plants were provided by this study as well. This study provides important information about the reconstruction of paleoflora, paleoclimate, stratygraphy of the Holocene, etc $(6,14,15$ and 16). The study in Holocene deposits also provides the factors which have their impact on the potential transformation of the flora in Elbasan district. $(8,9,10)$. The specimens were examined and photographed at 400x magnification Biolamp microscope. This study was undertaken with the purpose to show the correlation among the quantities data of spores and evolution over the years of Labiatae and Ranunculaceae families.

\section{MATERIALS AND METHODS}


During this study we have taken 16 soil samples, starting from 4 meters depth to $0.25 \mathrm{~m}$. The distance between the sampling stations is $0.25 \mathrm{~m}$. Palynological examination of all samples showed that all contained a large amount of organic matter that appeared suitable for pollen analysis. For each soil sample we have prepared 10 microscopic preparations.

\section{THE METHOD OF ACETOLYSIS ACCORDING TO ERDTMAN.}

The soil sampling is based on Erdtman method (3,4). Erdtman acetolyze method consists on processing the material with an acetolyze mixture, acetic anhydride $\left(\mathrm{CH}_{3} \mathrm{COO}\right)_{2}$ and sulfuric acid $\left(\mathrm{H}_{2} \mathrm{SO}_{4}\right)$ in a 9:1 ratio. In order to get better results first mix $1 \mathrm{~cm}^{3}$ soil with $10 \mathrm{ml} \mathrm{KOH} \mathrm{(10 \% ).} \mathrm{After} \mathrm{that} \mathrm{we} \mathrm{cleaned} \mathrm{it} \mathrm{with} \mathrm{distillated} \mathrm{water,} \mathrm{and} \mathrm{then} \mathrm{we} \mathrm{mixed} \mathrm{it}$ with acetolyze solution, until a neutral environment is obtained. The emasculation process is followed by a centrifugal process for three minutes (3000 rotation/minute). After that, granules were placed on slide and were observed with a microscope by dropping a drop from glycerin solution and water in a ratio 1:1. The acetolyze method is widely used in palynology; it gives better visibility over the spores and pollens compared with the other methods used during the microscopic observation process. $(1,2,11,13)$. We then use this method to assess the paleoclimate and paleoelevation represented by the assemblage and will discuss the results in terms of their implications for the uplift history of the Elbasan region.

\section{FIXTURE OF PREPARED COMPOSITES.}

The fixture of prepared composites was realized by using the method of glue-preparations through gel-glycerin. The gel-glycerin was prepared based on the Kisser method (12) by using $50 \mathrm{gr}$ of gelatin, $175 \mathrm{ml}$ of distillate water, $150 \mathrm{gr}$ glycerin, $7 \mathrm{gr}$ phenol (crystals). Once the distillate water was heated up to $50^{\circ} \mathrm{C}$, the gel was dropped into it. It was mixed up several times till melted properly. Then the glycerin and the composite were added and boiled till the liquid became thicker and viscose. After the phenol was added to the mixture, a uniform melted composition was taken. The prevention of air bubbles that might emerge during the process of composite preparation was made by warming up in advance all equipment used over the process. The final composite was isolated to the edges of microscope slide with spray or paraffin and after 3 days it was ready to be used and stored.

\section{RESULTS AND DISCUSSIONS}

On table 1 are presented the data about the number of spores for both two Labiatae and Ranunculaceae families according to the depth. Also is presented and the total number of spores for each of two families.

\begin{tabular}{|c|c|c|c|c||}
\hline Sample & $\begin{array}{c}\text { Depth } \\
\text { (meters) }\end{array}$ & $\begin{array}{c}\text { Number of spores } \\
\text { (Labiatae) }\end{array}$ & $\begin{array}{c}\text { Number of spores } \\
\text { (Ranunculaceae) }\end{array}$ & $\begin{array}{c}\text { Total number of spores } \\
\text { according to the depth }\end{array}$ \\
\hline 1 & 4 & 68 & 53 & 121 \\
\hline 2 & 3.75 & 69 & 56 & 125 \\
\hline 3 & 3.5 & 80 & 53 & 133 \\
\hline 4 & 3.25 & 89 & 57 & 146 \\
\hline 5 & 3 & 96 & 64 & 160 \\
\hline 6 & 2.75 & 93 & 70 & 163 \\
\hline 7 & 2.5 & 112 & 72 & 184 \\
\hline 8 & 2.25 & 115 & 82 & 201 \\
\hline 9 & 2 & 125 & 76 & 217 \\
\hline 10 & 1.75 & 135 & 82 & \\
\hline
\end{tabular}




\begin{tabular}{||c|c|c|c|c||}
\hline 11 & 1.5 & 136 & 84 & 220 \\
\hline 12 & 1.25 & 145 & 87 & 232 \\
\hline 13 & 1 & 161 & 86 & 247 \\
\hline 14 & 0.75 & 175 & 88 & 263 \\
\hline 15 & 0.5 & 181 & 92 & 273 \\
\hline 16 & 0.25 & 193 & 96 & 289 \\
\hline \multicolumn{2}{|c|}{$\begin{array}{c}\text { Total number of } \\
\text { spores }\end{array}$} & 1973 & 1198 & 750 \\
\hline
\end{tabular}

Table 1. Number of spores according to the depth

The maximum number of spores of Labiatae family (193 spores per sample) is taken in $0.25 \mathrm{~m}$ of depth while the minimum number is taken in $4 \mathrm{~m}$ of depth. Regarding to the Ranunculaceae family the maximum number of spores (96 spores per samples) also is taken close to surface, $0.25 \mathrm{~m}$ of depth. On figure 1 is clearly shown the increasing number of spores of Labiatae and Ranunculaceae families from the bottom to the surface.

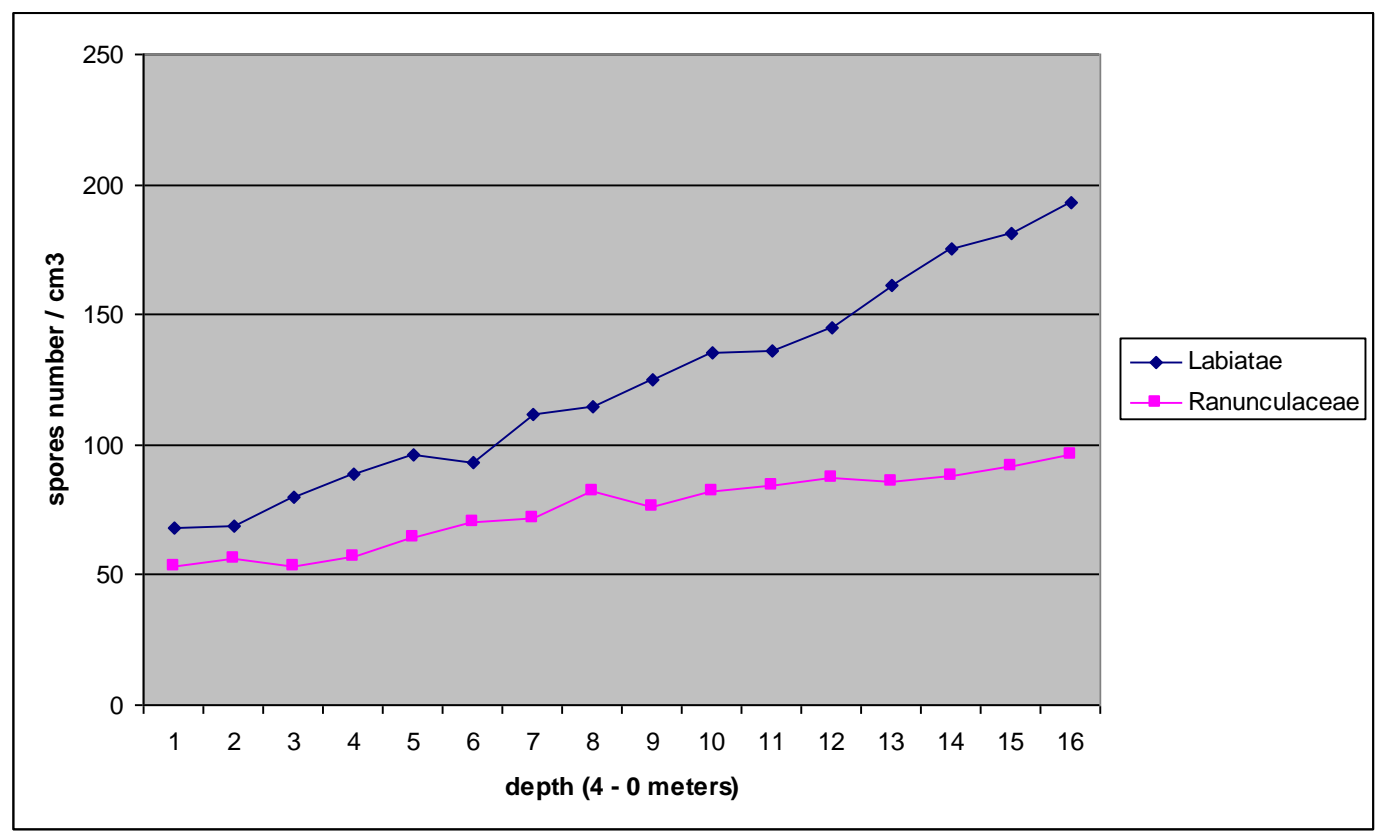

Figure 1. The spore's dispersion of Labiatae and Ranunculaceae families according to the depth

Based on the data presented in table 1 and figure 2 the spore's total number of Labiatae family is greater than that of Ranunculaceae family, respectively 1973 and 1198 spores. (Figure 2): In sample 16, belonging to 0.25 meters depth the number of spores of Labiatae family is 193. (Photo 1). The data show that the increase of the representative's presence of Labiatae family during all time may is connected with the human impact in arable lands, finding as the ubiquitous plant area over the years in Elbasan city (7). The forms cultivated for millennia play a major role in animal husbandry. 


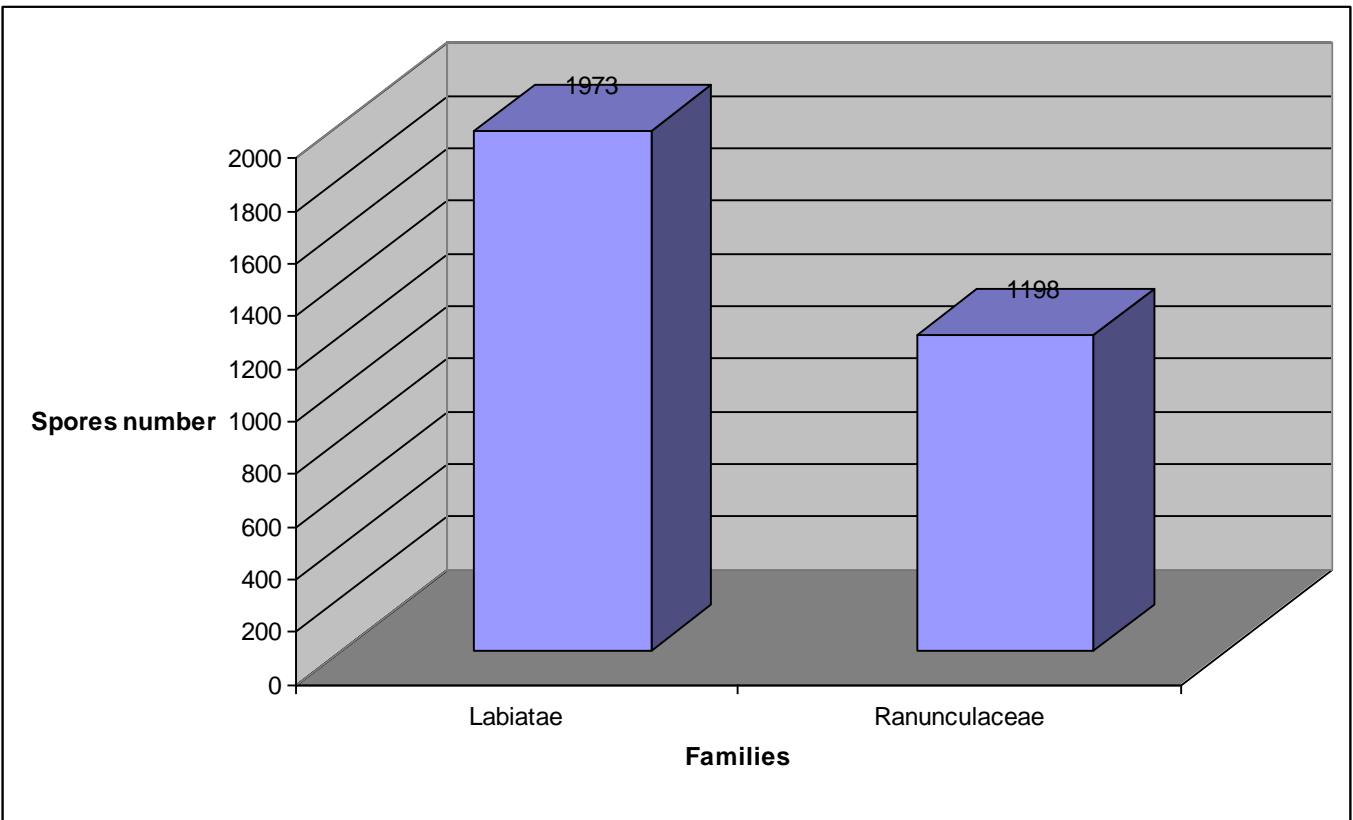

Figure 2. The total number of spores according to Labiatae and Ranunculaceae families

The dispersion rate of family Labiatae spores for different samples is presented (Figure 3):

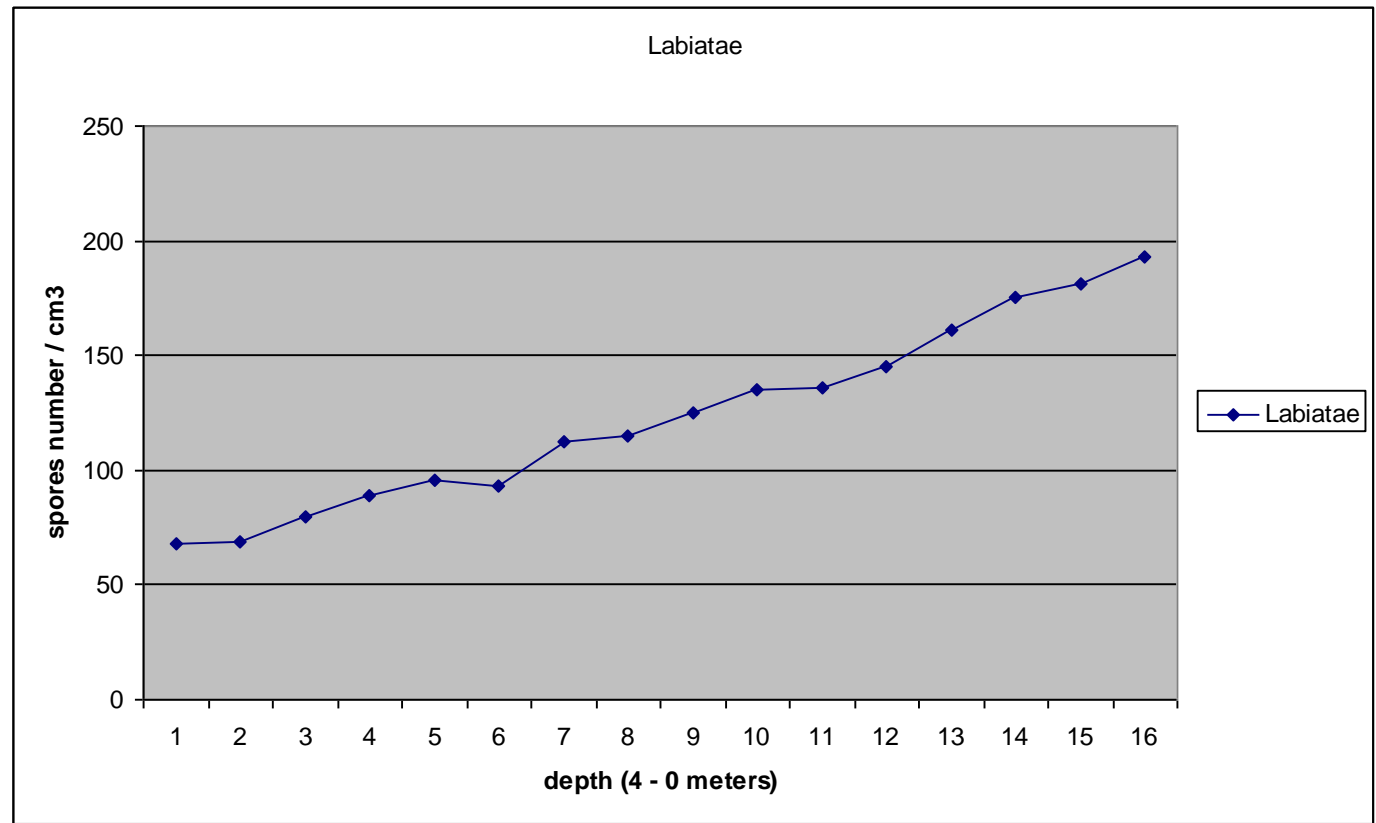

Figure 3. The spore's dispersion of Labiatae family according to the depth

In the figure 4 is presented the dispersion spores of the Ranunculaceae family from the bottom to the surface (Photo 2). These family representatives are distributed throughout varied zones.

The data show that the increase of the representative's presence of family Ranunculaceae from the bottom to the surface should be associated with human impact on the cultivation of the Ranunculaceae family as ornamental plants and above all given the geographical position of Elbasan region, being defined as a zone of the field, point out the fact that the significant presence of Ranunculaceae family plants. (7). 


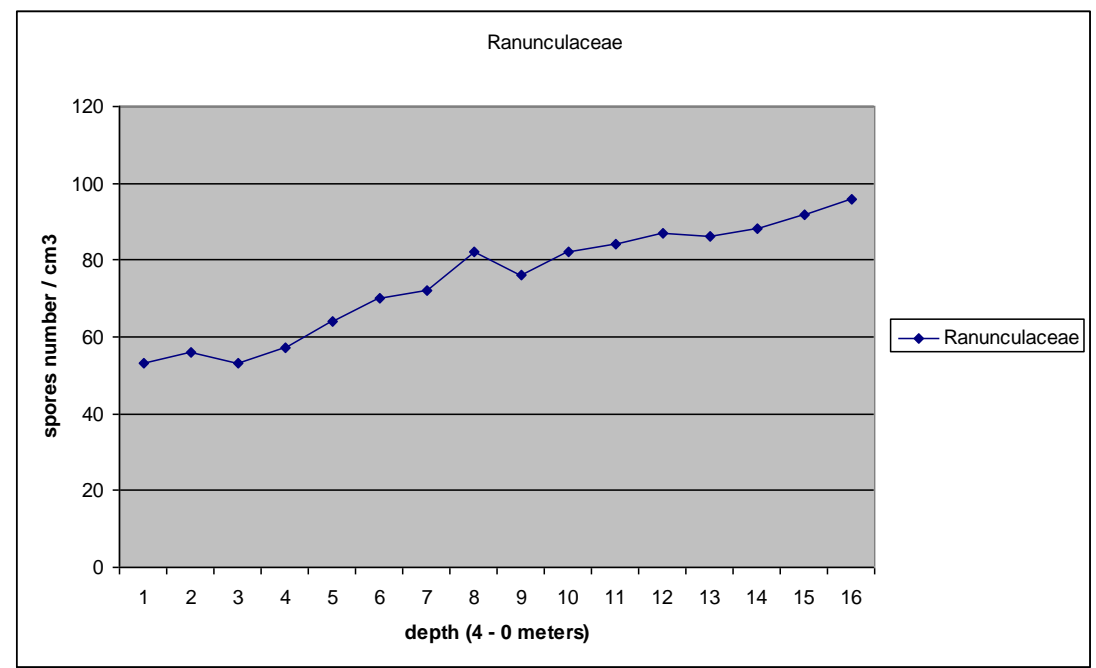

Figure 4. The spore's dispersion of Ranunculaceae family according to the depth

Elbasan city crowns today is mainly composed of fruit trees and a rich vegetation grass, the major part of which is cultivated. The main cause during the crowns transformations of Elbasan city should be associated with human activity impact. It is very well known the impact of ecological and human factor to the pollen grains dispersion $(2,6,17)$.

The quantitative data through spores and pollens variety of Labiataeae and Ranunculaceae families shows the direction of evolution of these two families mentioned in the study (8, $10)$.

\section{CONCLUSIONS}

This paleopalynological study of the microfossils plants of Labiatae and Ranunculaceae families, concluded as follows:

1. The total number spores of Labiatae family are greater than this of Ranunculaceae family.

2. The spore's number of Labiatae and Ranunculaceae families increases from the bottom to the surface.

3. Because of in Elbasan region not had natural and climate factors that have influenced in the vegetation change; we are mostly of the opinion that vegetation changes reported over the years are mainly related to the impact of human hand cultivation of useful plants.

Appendix 1. Microscopic photos
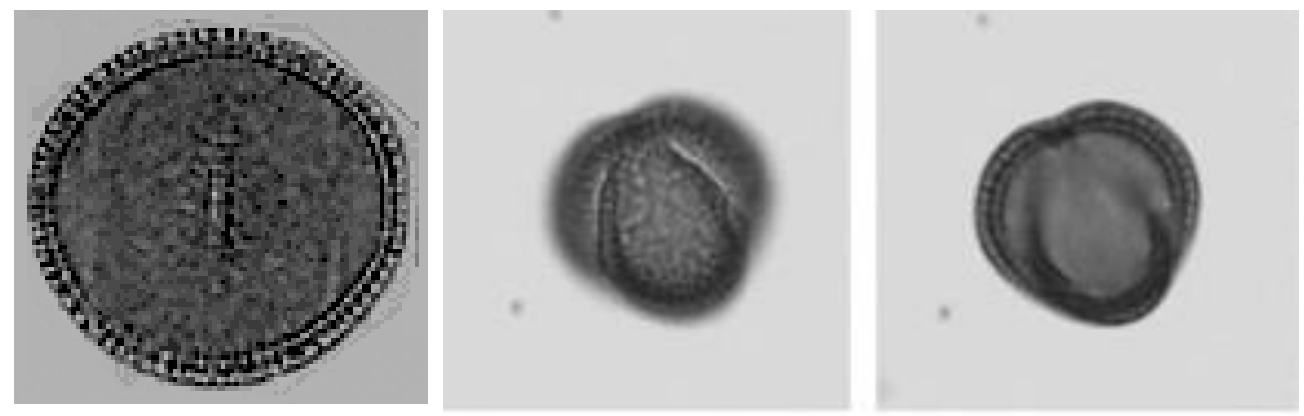

\section{REFERENCES}

(1) L. A. Aleshina, O plici tikvenih. - Bot. Zhurnal, Moskva, 12, pp1773-1778, 1964. 
(2) O. K. Davis, Preliminary pollen analysis of Neocene and Holocene sediment of the Great Salt Lake, U.S.A. - Proceedings Pliocene Conference, AASP Contribution, Arizona, 34, pp227-240, 1999.

(3) G. Erdtman, The acetolysis method. A revised description. Svensk Botanisk Tidskrift, 54, pp561-564, 1960.

(4) G. Erdtman, Handbook of palynology. An introduction to the study of pollen grains and spores. Hafner Publishing Company, New York, pp486, 1969.

(5) K. Faegri, Morfologia pilci dija prakticeskih cellej. - Bot. Zhurnal, Moskva, 1, pp2031, 1957.

(6) C. E. Forest, J. A. Wolfe, P. Molnar and K. A. Emanuel, Paleoaltimetry incorporating atmospheric physics and botanical estimates of paleoclimate. - Bulletin of the Geological Society of America, 111, pp497-511, 1999.

(7) Group of authors, Elbasani Enciklopedi. - Sejko, Elbasan, pp750, 2004.

(8) A. Jançe, G. Kapidani, Palynological data of Compositae and Umbelliferae families during Holocene Period in Elbasan city - J. Int. Environmental Application \& Science, (JIEAS - 2011), Vol. 6, No. 5, pp729-733, 2011.

(9) G. Kapidani, Bazat e Palinologjisë. - Sejko Infoservis, Elbasan, pp230, 1996.

(10) G. Kapidani, A. Jançe, Të dhëna të pjesshme mbi studimin e sporeve dhe poleneve në depozitimet e Kuaternarit në qytetin e Elbasanit. - Buletini Shkencor UE, Elbasan, 1, pp58-65, 2004.

(11) G. Kapidani, Fjalori i Terminologjisë Palinologjike. - Sejko, Elbasan, pp149, 2005.

(12) J. Kisser, Bemerkungen zum Einschluss in Glycerin-Gelatine. Z. wiss. Mikr. Berlin, pp51, 1935.

(13) P. D. Moore, J. A. Webb, An illustrated Guide to Pollen Analysis. - Department of Plant Sciences, King's College, Hodder and Stoughton, London, 133, pp216-217, 1978.

(14) P. Muhameti, E. Gjani and R. Roqi, Palinostratigrafia e depozitimeve të Tortonianit në pjesën lindore të Ultësirës pranë Adriatikut në bazë të studimit të sporopoleninit. Buletini Nafta dhe Gazi, Fier, pp204, 1984.

(15) E. Pacini, G. G. Franchi, Il polline: Biologia e Aplicazioni. - Quaderni di biologia, Bologna, 12, pp8-53, 1978.

(16) M. Shalla, A. Xhomo, A. Kodra and Z. Xhafa, Gjeologjia e Shqipërisë. - Shtëpia Botuese "Naim Frashëri", Tiranë, pp343, 1983.

(17) A. Jance, G. Kapidani, Palynological data of Compositae and Umbelliferae families during Quaternary Period in Elbasan city. Journal International of.Environmental Application \& Science (JIEAS), Vol. 6 (5): pp729-733, 2011. 